Aleksandar Rasovic | Vladimir Blagojevic | Marija Baranac-Stojanovic Erich Kleinpeter | Rade Markovic| Dragica M. Minic

\title{
Quantification of the push-pull effect in 2-alkylidene-4-oxothiazolidines by using NMR spectral data and barriers to rotation around the $\mathrm{C}=\mathrm{C}$ bond
}

Suggested citation referring to the original publication:

New J.Chem. 40 (2016), pp. 6364-6373

DOI http://dx.doi.org/10.1039/C6NJ00901H

ISSN (online) 1369-9261

ISSN (print) 1144-0546

Postprint archived at the Institutional Repository of the Potsdam University in:

Postprints der Universität Potsdam

Mathematisch-Naturwissenschaftliche Reihe ; 322

ISSN 1866-8372

http://nbn-resolving.de/urn:nbn:de:kobv:517-opus4-394523 

CrossMark $\leftarrow$ click for updates

Cite this: New J. Chem., 2016, 40,6364

Received (in Montpellier, France) 20th March 2016,

Accepted 9th May 2016

DOI: 10.1039/c6nj00901h

www.rsc.org/njc

\title{
Quantification of the push-pull effect in 2-alkylidene-4-oxothiazolidines by using NMR spectral data and barriers to rotation around the $\mathrm{C}=\mathrm{C}$ bond $\dagger$
}

\author{
Aleksandar Rašović, ${ }^{\star a}$ Vladimir Blagojević, ${ }^{\mathrm{b}}$ Marija Baranac-Stojanović, ${ }^{c}$ \\ Erich Kleinpeter, ${ }^{d}$ Rade Marković $\ddagger^{\text {ac }}$ and Dragica M. Miniće
}

\begin{abstract}
Information about the strength of donor-acceptor interactions in push-pull alkenes is valuable, as this so-called "push-pull effect" influences their chemical reactivity and dynamic behaviour. In this paper, we discuss the applicability of NMR spectral data and barriers to rotation around the $\mathrm{C}=\mathrm{C}$ double bond to quantify the push-pull effect in biologically important 2-alkylidene-4-oxothiazolidines. While olefinic proton chemical shifts and differences in ${ }^{13} \mathrm{C}$ NMR chemical shifts of the two carbons constituting the $\mathrm{C}=\mathrm{C}$ double bond fail to give the correct trend in the electron withdrawing ability of the substituents attached to the exocyclic carbon of the double bond, barriers to rotation prove to be a reliable quantity in providing information about the extent of donor-acceptor interactions in the push-pull systems studied. In particular all relevant kinetic data, that is the Arrhenius parameters (apparent activation energy $E_{a}$ and frequency factor $A$ ) and activation parameters $\left(\Delta S^{\ddagger}, \Delta H^{\ddagger}\right.$ and $\left.\Delta G^{\ddagger}\right)$, were determined from the data of the experimentally studied configurational isomerization of $(E)-9 a$. These results were compared to previously published related data for other two compounds, (Z)-1b and (2E,5Z)-7, showing that experimentally determined $\Delta G^{\ddagger}$ values are a good indicator of the strength of push-pull character. Theoretical calculations of the rotational barriers of eight selected derivatives excellently correlate with the calculated $\mathrm{C}=\mathrm{C}$ bond lengths and corroborate the applicability of $\Delta G^{\ddagger}$ for estimation of the strength of the push-pull effect in these and related systems.
\end{abstract}

\section{Introduction}

Compounds containing a thiazolidine ring have a rich and diverse chemistry and wide applications in the chemical industry and medicine. ${ }^{1}$ Interest in these compounds dates back to the $1940 \mathrm{~s}$, when it was discovered that penicillin $\mathrm{G}$ and other penicillins contain a bicyclic nucleus, which includes both a beta-lactam ring and a thiazolidine ring. This finding initiated a still growing interest in the synthesis, chemistry and detailed structure-biological activity studies on thiazolidines and related compounds. ${ }^{1}$

\footnotetext{
${ }^{a}$ Center for Chemistry ICTM, University of Belgrade, Studentski trg 16, P. O. Box 473, 11000 Belgrade, Serbia.E-mail: arasovic@chem.bg.ac.rs; Fax: +381-11-2636-061; Tel: +381-11-3336-740

${ }^{b}$ Institute of Technical Sciences, Serbian Academy of Sciences and Arts, Knez-Mihailova 35/IV, P.O. Box 377, 11000 Belgrade, Serbia

${ }^{c}$ Faculty of Chemistry, University of Belgrade, Studentski trg 16, P. O. Box 158, 11001 Belgrade, Serbia

${ }^{d}$ Universität Potsdam, Chemisches Institut, Karl-Liebknecht-Str. 24-25, D-14476 Potsdam (Golm), Germany

${ }^{e}$ State University in Novi Pazar, Vuka Karadžića bb, 36300, Novi Pazar, Serbia $\dagger$ Electronic supplementary information (ESI) available. See DOI: 10.1039/c6nj00901h ‡1946-2012.
}

2-Alkylidene-4-oxothiazolidine derivatives $\mathbf{1}$, which were synthesized in our laboratory, have attracted attention owing to their potential biological activity ${ }^{1,2}$ and as substrates for a number of selective transformations leading to various heterocyclic systems, ${ }^{1 i}$ such as $3,3 a \lambda^{4}, 4$-trithia-1-azapentalenes $2,,^{3,4}$ 1,3-thiazines $3^{3}$ and other thiazolidine derivatives $4-7^{5-8}$ and $\mathbf{8}^{3,9}$ (Scheme 1).

An important feature of these compounds, that determines their properties, dynamic behaviour and chemical reactivity, is the electronic interaction between electron donating $\left(\mathrm{N}_{\text {ring }}, \mathrm{S}_{\text {ring }}\right)$ and electron withdrawing groups $\left(\mathrm{R}_{1} \mathrm{CO}\right.$ in Scheme 1$)$, which occurs via the $\mathrm{C}=\mathrm{C}$ double bond. Thus, these compounds belong to the class of push-pull alkenes, ${ }^{10}$ best represented by the hybrid structure I, containing electron donating groups (Don) at one end of the partial $\mathrm{C}=\mathrm{C}$ double bond and electron withdrawing groups (EWG) at the other end (Scheme 2).

As a result of these electronic interactions (the push-pull effect), the $\pi$-bond order of the double bond is reduced (decreasing the rotational barrier $\Delta G^{\#} ; \mathbf{B}-\mathbf{E}$, Scheme 2) and, conversely, the bond orders of the C-Don and C-EWG bonds are increased (B-D in Scheme 2). Therefore, the barrier to rotation around the 


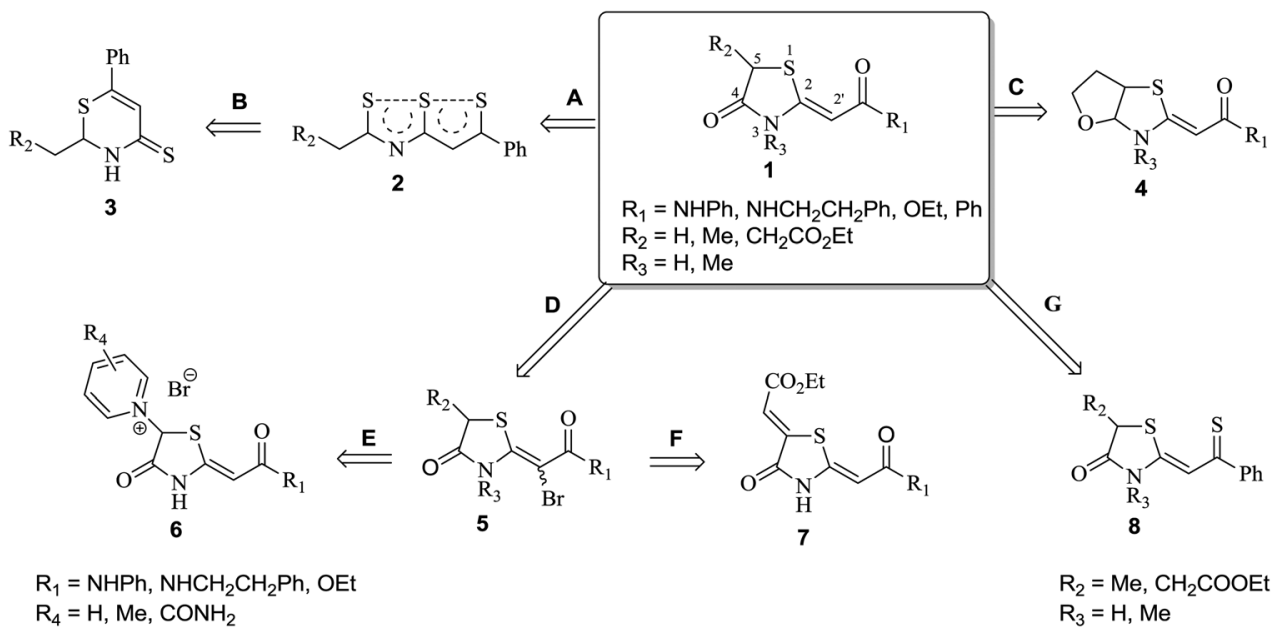

Scheme 1 2-Alkylidene-4-oxothiazolidines 1 as precursors for a number of selective transformations into various heterocyclic systems.

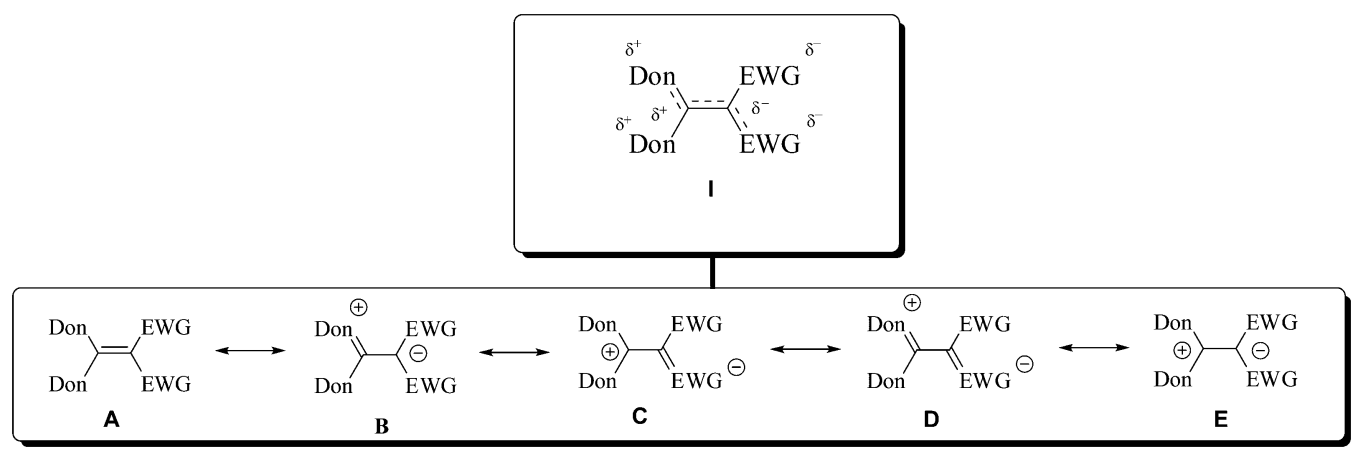

Scheme 2 Resonance structures of push-pull alkenes.

$\mathrm{C}=\mathrm{C}$ double bond in this type of compound could be employed to quantify the push-pull effect. ${ }^{10 a-c} \Delta G^{\#}$ is readily obtained by dynamic NMR spectroscopy (DNMR) or can be theoretically calculated. In addition to $\Delta G^{\#}$, other parameters often used as a measure of the push-pull effect are: (i) ${ }^{13} \mathrm{C}$ NMR chemical shift difference $\Delta \delta_{\mathrm{C}=\mathrm{C}}$ between the two carbon atoms of the $\mathrm{C}=\mathrm{C}$ double bond, ${ }^{10 b, e, g, i}$ (ii) the bond length of the central partial $\mathrm{C}=\mathrm{C}$ double bond, ${ }^{10 c, h}$ experimentally available by X-ray analysis and (iii) the quotient of the occupation numbers of the $\pi^{*}$ antibonding and $\pi$ bonding orbitals $\left(\pi^{*} / \pi\right)$ of the $\mathrm{C}=\mathrm{C}$ double bond, available from theoretical calculations combined with Natural Bond Orbital (NBO) analysis. ${ }^{10 c, i}$ Although the occupation quotient $\left(\pi^{*} / \pi\right)$ can be regarded as a sensitive parameter for quantification of the push-pull effect with a broader scope than the other quantities $\left(\Delta G^{\#}, \Delta \delta_{\mathrm{C}=\mathrm{C}}\right.$ and bond length) ${ }^{10 c, i}$ a general parameter to quantify the push-pull effect is not yet available due to the $\left(\pi^{*} / \pi\right)$ parameter dependence on the type and number of substituents at the push-pull $\mathrm{C}=\mathrm{C}$ double bond.

We have recently shown that 4-oxothiazolidine-2-ylidene thioketones 8 (Scheme 1), containing a cis-oriented $\mathrm{S}-\mathrm{C}=\mathrm{C}-\mathrm{C}=\mathrm{S}$ moiety, represent an excellent model for investigating the influence of the push-pull effect and 1,5-type weak noncovalent $S \cdots S$ interactions on the ring-opening-closing mode of 4-oxothiazolidine to $3,3 a \lambda^{4}$, 4-trithia-1-azapentalene transformation (reaction $\mathbf{A}$ in Scheme 1). ${ }^{3,4}$
As a continuation of our studies related to evaluating the strength of the push-pull character in 2-alkylidene-4-oxothiazolidine derivatives and its influence on their chemical reactivity and dynamic behaviour, we report herein a study on: (i) NMR spectroscopic data of thiazolidine thioamide derivatives 9a-c, not yet reported, compared to data for previously synthesized compounds 1 and 8, with the aim of finding out whether both $\Delta \delta_{\mathrm{C}=\mathrm{C}}$ parameters and $=\left(\mathrm{C}^{\prime}\right)-H$ proton chemical shifts could be applied for the quantification of their push-pull effect, (ii) experimentally determined barrier to rotation around the $\mathrm{C}=\mathrm{C}$ double bond in (E)-(5-ethoxycarbonylmethyl-4-oxothiazolidin2-ylidene)ethanthioamide 9a (Fig. 1) and its relation to our previously reported experimental rotational barriers ${ }^{11}$ of related analogs and (iii) having found the correct trend, eight derivatives were selected for computational studies. Seven of them differ in the $\mathrm{R}_{1} \mathrm{CX}$ substituent attached to the $\mathrm{C}\left(2^{\prime}\right)$ atom, for which we expect the strongest influence on $\mathrm{C}(2)=\mathrm{C}\left(2^{\prime}\right)$ charge polarization. They are: $\mathbf{1 b}\left(\mathrm{R}_{1} \mathrm{CX}=\mathrm{COPh}\right), \mathbf{1 d}\left(\mathrm{R}_{1} \mathrm{CX}=\mathrm{CONHPh}\right)$, 1e $\left(\mathrm{R}_{1} \mathrm{CX}=\mathrm{CONH}\left(\mathrm{CH}_{2}\right)_{2} \mathrm{Ph}\right), 1 \mathrm{~g}\left(\mathrm{R}_{1} \mathrm{CX}=\mathrm{CO}_{2} \mathrm{Et}\right)$, 8a $\left(\mathrm{R}_{1} \mathrm{CX}=\right.$ $\mathrm{CSPh})$, 9a $\left(\mathrm{R}_{1} \mathrm{CX}=\mathrm{CSNH}_{2}\right)$ and $9 \mathrm{c}\left(\mathrm{R}_{1} \mathrm{CX}=\mathrm{CSNH}\left(\mathrm{CH}_{2}\right)_{2} \mathrm{Ph}\right)$ (Table 2). In addition, compound 7 , which has the same $\mathrm{R}_{1} \mathrm{CX}$ as $1 \mathrm{~g}$, but a $\mathrm{C}(5)=\mathrm{C}\left(5^{\prime}\right)$ double bond instead of the $\mathrm{C}(5)-\mathrm{C}\left(5^{\prime}\right)$ single bond in $\mathbf{1 g}$ was included to find if subtle effects coming from a remote group are reflected in the barrier values. 


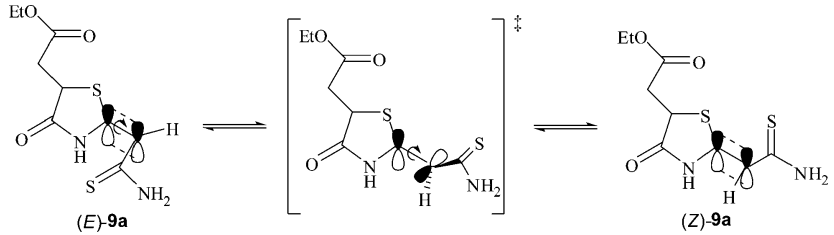

Fig. 1 The configurational isomerization of 2-alkylidene-4-oxothiazolidine derivative $(E)-9 a$

We also wish to note that the literature is rather scarce on a description of a method for the isolation of pure $E$ isomers of these compounds and their spectral properties. Interestingly and surprisingly, ${ }^{11-14}$ thiazolidine derivative 9 a was isolated from the reaction mixture by filtration (ethanol solution) and recrystallized from $96 \%$ ethanol to provide a final product as the pure $E$ isomer.

\section{Methodology}

\subsection{Experimental}

(4-Oxothiazolidin-2-ylidene)ethanethioamides 9a-c (Table 2) were synthesized according to our previously reported procedure, ${ }^{14}$ including a slight modification: the catalyst $\left(\mathrm{K}_{2} \mathrm{CO}_{3}\right)$ was used in $4.5 \mathrm{~mol} \%$ of the starting material.

Variable temperature ${ }^{1} \mathrm{H}$ NMR measurements were carried out on a Bruker AC-300 spectrometer. The NMR probe temperatures were calibrated using a non-magnetic digital thermocouple with the lead inserted in the sample tube at receiver coil level. Hence, the achieved accuracy of the temperature calibration was better than \pm 0.5 degrees. The samples were equilibrated at the given temperatures.

The ${ }^{1} \mathrm{H}$ NMR and ${ }^{13} \mathrm{C}$ NMR data of the configurational isomers (E)-9a and (Z)-9a, fully shown below, provide a fairly complete picture of this isomeric equilibrium. Monitoring of the stereodynamic behaviour associated with the isomerization rate of $(E)$-9a to $(Z)-9$ a was performed in DMSO- $d_{6}$ solutions at 298, 303 and $308 \mathrm{~K}$. The $E / Z$ ratios were determined by the integration of the signals at $\delta 5.64$ and $\delta 6.15 \mathrm{ppm}$, assigned to the $\mathrm{C}\left(2^{\prime}\right)-H$ protons of $(E)-9 \mathbf{a}$ and (Z)-9a, respectively. The facile $E$ to $Z$ isomerization at $298 \mathrm{~K}$ is illustrated in Fig. 2 by the three ${ }^{1} \mathrm{H}$ NMR spectra recorded 5, 170 and 1380 minutes after the dissolution of $(E)-9 a$. Typical conditions for recording ${ }^{1} \mathrm{H}$ NMR spectra were as follows: sixteen scans, spectral width of $10330 \mathrm{~Hz}$ with 65536 data points, relaxation delay of $1 \mathrm{~s}$ and acquisition time of $3.17 \mathrm{~s}$.

Structural assignments of the isolated products $(E)-\mathbf{9 a},(Z)-\mathbf{9 b}$ and (Z)-9c were made on the basis of spectroscopic data (IR, ${ }^{1} \mathrm{H}$ NMR and ${ }^{13} \mathrm{C}$ NMR, MS) and elemental analysis. For example, compared to the $Z$-isomers the $\delta$ values of the $\mathrm{C}\left(2^{\prime}\right)-H$ proton for the $E$-isomers appear at a higher field. On the other hand, the $\mathrm{N} H$ lactam proton of the $E$-counterparts is observed at a lower field (Fig. 2).

\section{NMR spectral data of thiazolidine derivatives 9a-c}

(E)-(5-Ethoxycarbonylmethyl-4-oxothiazolidin-2-ylidene)ethanthioamide (9a). ${ }^{1} \mathrm{H}$ NMR (DMSO- $\left.d_{6}\right): \delta 1.18\left(3 \mathrm{H}, \mathrm{t}, J=7.2 \mathrm{~Hz}, \mathrm{CH}_{3}\right)$, 3.05-3.09 (2H, m, $\left.\mathrm{CH}_{\mathrm{A}} \mathrm{H}_{\mathrm{B}} \mathrm{COO}\right), 4.09\left(2 \mathrm{H}, \mathrm{q}, J=7.2 \mathrm{~Hz}, \mathrm{CH}_{2} \mathrm{O}\right)$,

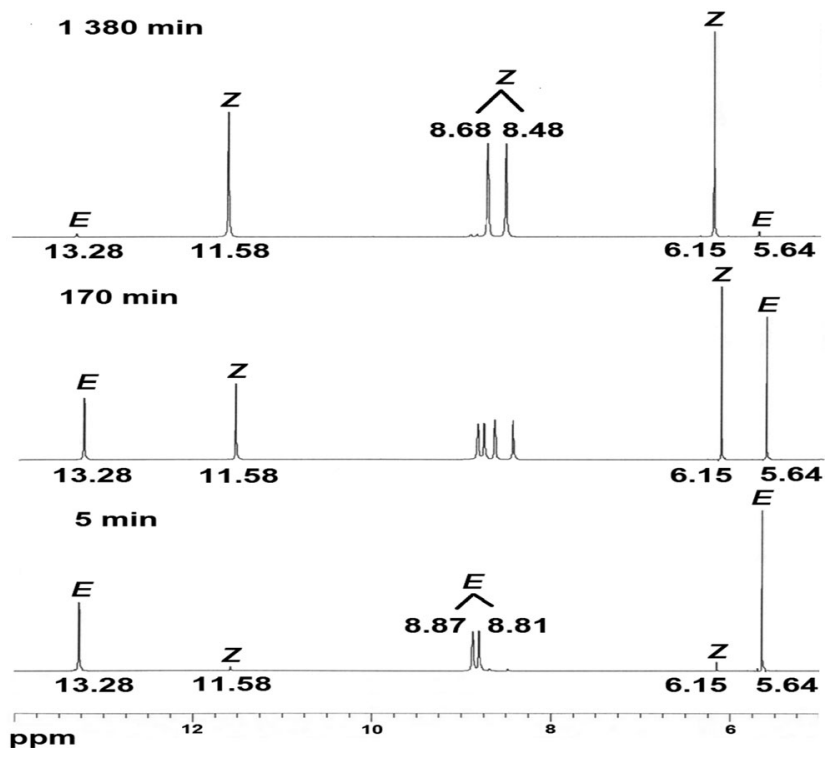

Fig. 2 Partial ${ }^{1} \mathrm{H}$ NMR spectra of $9 \mathrm{a}$ in DMSO $-d_{6}$ at $298 \mathrm{~K}$, recorded $5 \mathrm{~min}$, $170 \mathrm{~min}$ and $1380 \mathrm{~min}$ after dissolution of the $E$ isomer.

4.45-4.51 (1H, m, $\left.\mathrm{CH}_{\mathrm{X}} \mathrm{S}\right), 5.64(1 \mathrm{H}, \mathrm{s},=\mathrm{CH}), 8.81-8.87(2 \mathrm{H}, \mathrm{d}$, $\mathrm{NH}_{\text {amide }}$ ), $13.28\left(1 \mathrm{H}, \mathrm{s}, \mathrm{NH}_{\text {lactam}}\right) ;{ }^{13} \mathrm{C}$ NMR (DMSO- $\left.d_{6}\right): \delta 14.2$ $\left(\mathrm{CH}_{3}\right), 36.3\left(\mathrm{CH}_{2} \mathrm{COO}\right), 41.8\left(\mathrm{CH}_{\mathrm{X}} \mathrm{S}\right), 61.0\left(\mathrm{CH}_{2} \mathrm{O}\right), 97.2(=\mathrm{CH})$, $154.9(\mathrm{C}=), 170.4\left(\mathrm{CO}_{\text {ester }}\right), 174.4\left(\mathrm{CO}_{\text {lactam }}\right), 191.4(\mathrm{C}=\mathrm{S})$; MS (CI): $m / z 261(\mathrm{M}+1)^{+}$.

(Z)-(5-Ethoxycarbonylmethyl-4-oxothiazolidin-2-ylidene)ethanthioamide (9a). ${ }^{1} \mathrm{H}$ NMR (DMSO- $\left.d_{6}\right): \delta 1.19\left(3 \mathrm{H}, \mathrm{t}, J=7.0 \mathrm{~Hz}, \mathrm{CH}_{3}\right)$, $2.89\left(1 \mathrm{H}, \mathrm{dd}, J=18.0 \mathrm{~Hz}, \mathrm{CH}_{A} \mathrm{H}_{\mathrm{B}} \mathrm{COO}\right), 2.99(1 \mathrm{H}, \mathrm{dd}, J=18.0 \mathrm{~Hz}$, $\mathrm{CH}_{\mathrm{A}} H_{B} \mathrm{COO}$ ), 4.09 (2H, q, $\left.J=7.0 \mathrm{~Hz}, \mathrm{CH}_{2} \mathrm{O}\right), 4.04-4.15(1 \mathrm{H}, \mathrm{m}$, $\mathrm{CH}_{\mathrm{X}} \mathrm{S}$ ) overlapped with the signal assigned to the $\mathrm{CH}_{2} \mathrm{O}$ protons, $6.15(1 \mathrm{H}, \mathrm{s},=\mathrm{CH}), 8.48-8.68\left(2 \mathrm{H}, \mathrm{d}, \mathrm{NH}_{\text {amide }}\right), 11.58(1 \mathrm{H}$, $\left.\mathrm{s}, \mathrm{NH}_{\text {lactam}}\right) ;{ }^{13} \mathrm{C} \mathrm{NMR}\left(\mathrm{DMSO}-d_{6}\right): \delta 14.2\left(\mathrm{CH}_{3}\right), 36.4\left(\mathrm{CH}_{2} \mathrm{COO}\right)$, $42.5\left(\mathrm{CH}_{\mathrm{X}} \mathrm{S}\right), 60.8\left(\mathrm{CH}_{2} \mathrm{O}\right), 100.8(=\mathrm{CH}), 156.9(\mathrm{C}=), 170.6$ $\left(\mathrm{CO}_{\text {ester }}\right), 175.3\left(\mathrm{CO}_{\text {lactam }}\right), 193.2(\mathrm{C}=\mathrm{S})$.

(Z)-(4-Oxothiazolidin-2-ylidene)ethanthioamide (9b). ${ }^{1} \mathrm{H}$ NMR (DMSO- $\left.d_{6}\right): \delta 3.61\left(2 \mathrm{H}, \mathrm{s}, \mathrm{CH}_{2} \mathrm{~S}\right), 6.16(1 \mathrm{H}, \mathrm{s},=\mathrm{CH}), 8.44-8.65$ $\left(2 \mathrm{H}, \mathrm{d}, \mathrm{NH}_{\text {amide }}\right), 11.51$ (1H, s, $\left.\mathrm{NH}_{\text {lactam }}\right) ;{ }^{13} \mathrm{C}$ NMR (DMSO- $\left.d_{6}\right)$ : $\delta 32.9\left(\mathrm{CH}_{2} \mathrm{~S}\right), 100.6(=\mathrm{CH}), 158.4(\mathrm{C}=), 174.4\left(\mathrm{CO}_{\text {amide }}\right), 193.2$ $(\mathrm{C}=\mathrm{S}) ; \mathrm{MS}(\mathrm{CI}): m / z 175(\mathrm{M}+1)^{+}$.

(Z)-(4-Oxothiazolidin-2-ylidene)-N-(2-phenylethyl)ethanthioamide (9c). ${ }^{1} \mathrm{H}$ NMR (DMSO- $\left.d_{6}\right): \delta 2.86\left(2 \mathrm{H}, \mathrm{t}, J=7.0 \mathrm{~Hz}, \mathrm{CH}_{2} \mathrm{Ph}\right), 3.62-$ $3.73\left(2 \mathrm{H}, \mathrm{m}, \mathrm{NCH}_{2}\right)$, the $\left(2 \mathrm{H}, \mathrm{s}, \mathrm{CH}_{2} \mathrm{~S}\right)$ signal is overlaped with the signal assigned to the $\left(\mathrm{NCH}_{2}\right)$ protons, $6.21(1 \mathrm{H}, \mathrm{s},=\mathrm{CH})$, 7.16-7.35 (5H, m, Ph), $9.58\left(1 \mathrm{H}, \mathrm{t}, J=5.2 \mathrm{~Hz}, \mathrm{NH}_{\text {amide }}\right), 11.51(1 \mathrm{H}$, $\left.\mathrm{s}, \mathrm{NH}_{\text {lactam }}\right) ;{ }^{13} \mathrm{C}$ NMR (DMSO- $\left.d_{6}\right): \delta 32.9\left(\mathrm{CH}_{2} \mathrm{~S}\right), 33.8\left(\mathrm{CH}_{2} \mathrm{Ph}\right)$, $45.5\left(\mathrm{NCH}_{2}\right), 101.2(=\mathrm{CH}), 126.4(p-\mathrm{Ph}), 128.7(o-\mathrm{Ph}), 128.8$ (m-Ph), $139.6\left(\mathrm{C}_{\text {ipso }}-\mathrm{Ph}\right), 156.1(\mathrm{C}=), 174.3$ (CO $\left.\mathrm{CO}_{\text {lactam}}\right), 190.4$ $(\mathrm{C}=\mathrm{S}) ; \mathrm{MS}(\mathrm{CI}): m / z 279(\mathrm{M}+1)^{+}$.

\subsection{Computational details}

Geometry optimization and frequency analysis of the $Z$ and $E$ isomers of the compounds studied was conducted at the 
M06-2X/6-311G** level, ${ }^{15,16}$ using the Gaussian 09 program package. ${ }^{17}$ Transition state structures were determined using the Synchronous Transit-Guided Quasi-Newton method ${ }^{18,19}$ at the M06-2X/6-311G** level. To account for solvent effects, the structures of the three derivatives, $\mathbf{1 b}, \mathbf{7}$ and $\mathbf{9 a}$, were re-optimized in chloroform and dimethylsulfoxide along with their TS, using the continuum solvation COSMO model (conductor-like screening model). ${ }^{20}$ All transition state structures were characterized by an imaginary frequency, the vibrational mode of which corresponded to the rotation around the $\mathrm{C}(2)-\mathrm{C}\left(2^{\prime}\right)$ bond.

The calculated and experimentally determined barriers to rotation for $\mathbf{1 b}, 7$ and 9a show an excellent correlation with a correlation coefficient of 0.996 (Table 1 and Fig. 3). The fact that the calculated barriers overestimate the experimental ones can be rationalized by taking into account that the effects of solutesolute and solute-solvent direct interactions were not completely considered by the theoretical calculations. Additionally, for these compounds, in the correlation of the calculated barriers to rotation with experimentally determined ones, other levels tried including B3LYP and MP2 methods with a 6-31G** basis set, as well as a M06-2X method with 6-31G** and cc-pvtz ${ }^{21}$ basis sets, led to similar results. However, in these calculations the use of the newly developed functional M06-2X reached the best agreement with experimental data.

Table 1 Experimental and calculated barriers to rotation $\left(\Delta G^{\#}\right.$ in $\mathrm{kJ} \mathrm{mol}^{-1}$; $T=298 \mathrm{~K})$ for the configurational isomerization of compounds $\mathbf{1 b}$, 7 and $9 a$

\begin{tabular}{lllrl}
\hline Compound & Solvent & Isomerization direction & $\Delta G^{\#}$ exp. & $\Delta G^{\#}$ calc. $^{b}$ \\
\hline 1b & Chloroform & $Z \rightarrow E$ & $98.5^{a}$ & 154.4 \\
7 & DMSO- $d_{6}$ & $E \rightarrow Z$ & $100.2^{a}$ & 169.1 \\
9a & DMSO- $d_{6}$ & $E \rightarrow Z$ & $96.6^{b}$ & 134.1
\end{tabular}

${ }^{a}$ Ref. $12 .^{b}$ This work.

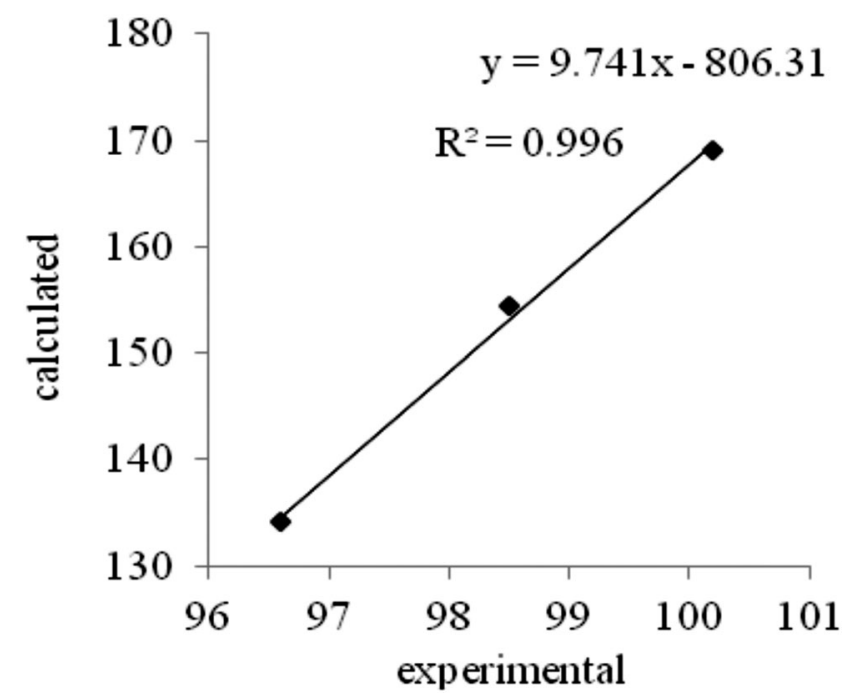

Fig. 3 Correlation between calculated and experimental barriers to rotation for compounds $\mathbf{1 b}, \mathbf{7}$ and $\mathbf{9 a}$. The respective values are given in Table 1.

\section{Results and discussion}

\subsection{General considerations}

This section is organized as follows. We first discuss the relia-

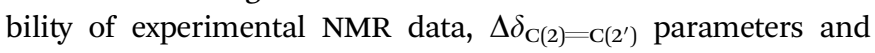
$\mathrm{C}\left(2^{\prime}\right) H$ proton chemical shift, to correctly reproduce the trend in push-pull activity as a function of the electronic properties of substituents attached to the thiazolidine ring. We will first concentrate on those at the exocyclic carbon of the $\mathrm{C}(2)=\mathrm{C}\left(2^{\prime}\right)$ double bond, since their influence is expected to be the strongest. This is followed by an analysis of experimentally obtained kinetic activation parameters for the configurational isomerization of $(E)-(9 a)$ in DMSO- $d_{6}$ and comparison with our previously reported data for thiazolidine enamino ketone $(Z)-\mathbf{1 b}$ and thiazolidine enamino ester $(2 E, 5 Z)-7$. Subsequently, we discuss the optimized geometries of ground and transition structures, which is followed by an analysis of the calculated rotational barriers for selected thiazolidines 1b, 1d, 1e, 1g, 7, 8a, 9a and 9c. In particular, our interest concerns whether the relative magnitudes of the barriers to rotation correspond to changes in the strength of the pushpull effect. For this purpose, we correlate the computed rotational barriers with the lengths of the $\mathrm{C}=\mathrm{C}$ bonds, which we previously showed to reflect changes in the extent of donor-acceptor interactions in comparable groups of compounds. ${ }^{10 i}$

\subsection{NMR parameters as a measure of the push-pull effect in 2-alkylidene-4-oxothiazolidine derivatives}

The selected experimental ${ }^{1} \mathrm{H}$ NMR and ${ }^{13} \mathrm{C}$ NMR chemical shifts for thiazolidine enamino thioamides $\mathbf{9 a - c}$ are presented in Table 2 (entries 13-17). For comparison purposes, the NMR spectral data of the closely related thiazolidine enamino thioketones 8a-c (entries 10-12), enamino ketones 1a-c (entries 1-3), enamino amides 1d-e (entries 4-6) and enamino esters $\mathbf{1 f - g}$ and 7 (entries 8 and 9) are included (the NMR spectral data for thiazolidines 1a-g,,$^{9,12,14,22} 7^{23}$ and $\mathbf{8 a}-\mathbf{c}^{9}$ have already been published). The data in Table 2 show that all compounds exhibit similar ${ }^{13} \mathrm{C}$ NMR spectral characteristics: the low field position of the signal corresponding to the $\mathrm{C}(2)$ atom at the donor side ( $\delta$ 151.9-166.0 ppm) and the high field position of the signal assigned to the $\mathrm{C}\left(2^{\prime}\right)$ atom at the acceptor side of the $\mathrm{C}=\mathrm{C}$ double bond ( $\delta$ 88.6-113.9 ppm). This large difference in the chemical shift values, $\Delta \delta_{\mathrm{C}(2)=\mathrm{C}\left(2^{\prime}\right)}$ ranging from $50.8 \mathrm{ppm}$ to $70.6 \mathrm{ppm}$, proves to be indicative of their push-pull character, that is significant charge polarization within the $\mathrm{C}=\mathrm{C}$ double bond. The $\Delta \delta_{\mathrm{C}(2)=\left(\mathrm{C2}^{\prime}\right)}$ values should increase with the increasing push-pull character of the double bond, as has been proven by previous calculations on several other push-pull systems. ${ }^{10 b, c, i}$ In addition, due to the enhanced shielding of the $\mathrm{C}\left(2^{\prime}\right)$ atom, the chemical shift of the hydrogen attached to it, $\delta\left(\mathrm{C}\left(2^{\prime}\right)-H\right)$, should actually decrease with an increasing push-pull effect.

However, as the data in Table 2 show, the olefinic ${ }^{1} \mathrm{H}$ NMR chemical shifts deviate from expectations, which is also the case with the $\Delta \delta_{\mathrm{C}(2)=\mathrm{C}\left(2^{\prime}\right)}$ parameters. Generally, the $\mathrm{C}\left(2^{\prime}\right)-H$ proton chemical shift values for enamino ketones 1a-c (6.78-6.95 ppm) and enamino thioketones 8a-c (7.43-7.61 ppm) are higher than those for enamino amides 1d-e (5.36-5.79 ppm), enamino thioamides 
Table 2 Selected experimental ${ }^{1} \mathrm{H}$ NMR and ${ }^{13} \mathrm{C}$ NMR (DMSO- $d_{6}$ ) chemical shifts (ppm) of compounds $\mathbf{1 a}-\mathbf{g}, \mathbf{7}, \mathbf{8 a}-\mathbf{c}$ and $\mathbf{9 a}-\mathbf{c}$

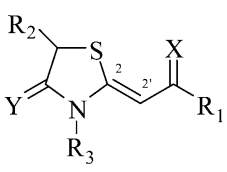

1a-g, 7, 8a-c, 9a-c

\begin{tabular}{|c|c|c|c|c|c|c|c|c|}
\hline Entry & Compound $\mathrm{X}(\mathrm{Y})=\mathrm{S}, \mathrm{O}$ & $\mathrm{R}_{1}$ & $\mathrm{R}_{2}$ & $\mathrm{R}_{3}$ & $\mathrm{C}\left(2^{\prime}\right)-H$ & $\mathrm{C}(2)$ & $\mathrm{C}\left(2^{\prime}\right)$ & $\Delta \delta_{\mathrm{C}(2)}=\mathrm{C}\left(2^{\prime}\right)$ \\
\hline 1 & $(Z)-\mathbf{1 a}(\mathrm{X}=\mathrm{O} ; \mathrm{Y}=\mathrm{O})$ & $\mathrm{Ph}$ & $\mathrm{CH}_{3}$ & $\mathrm{H}$ & 6.80 & 160.6 & 94.5 & 66.1 \\
\hline 2 & $(Z)-\mathbf{1 b}(\mathrm{X}=\mathrm{O} ; \mathrm{Y}=\mathrm{O})$ & $\mathrm{Ph}$ & $\mathrm{CH}_{2} \mathrm{COOEt}$ & $\mathrm{H}$ & 6.78 & 161.6 & 94.9 & 66.7 \\
\hline 3 & $(Z)-1 \mathrm{c}(\mathrm{X}=\mathrm{O} ; \mathrm{Y}=\mathrm{O})$ & $\mathrm{Ph}$ & $\mathrm{CH}_{2} \mathrm{COOEt}$ & $\mathrm{CH}_{3}$ & 6.95 & 161.2 & 95.5 & 65.7 \\
\hline 4 & $(Z)-\mathbf{1 d}(\mathrm{X}=\mathrm{O} ; \mathrm{Y}=\mathrm{O})$ & NHPh & $\mathrm{CH}_{2} \mathrm{COOEt}$ & $\mathrm{H}$ & 5.79 & 153.5 & 93.3 & 60.2 \\
\hline 5 & $(E)-\mathbf{1 d}(\mathrm{X}=\mathrm{O} ; \mathrm{Y}=\mathrm{O})$ & NHPh & $\mathrm{CH}_{2} \mathrm{COOEt}$ & $\mathrm{H}$ & 5.36 & - & - & - \\
\hline 6 & $(Z)-1 \mathrm{e}(\mathrm{X}=\mathrm{O} ; \mathrm{Y}=\mathrm{O})$ & $\mathrm{NH}(\mathrm{CH})_{2} \mathrm{Ph}$ & $\mathrm{H}$ & $\mathrm{H}$ & 5.59 & 151.9 & 92.7 & 59.2 \\
\hline 7 & $(Z)-\mathbf{1 f}(\mathrm{X}=\mathrm{O} ; \mathrm{Y}=\mathrm{O})$ & OEt & $\mathrm{H}$ & $\mathrm{H}$ & 5.44 & 159.2 & 88.6 & 70.6 \\
\hline 8 & $(Z)-1 \mathrm{~g}(\mathrm{X}=\mathrm{O} ; \mathrm{Y}=\mathrm{O})$ & OEt & $\mathrm{CH}_{2} \mathrm{COOEt}$ & $\mathrm{H}$ & 5.44 & 157.8 & 88.9 & 69.0 \\
\hline 9 & $(2 E, 5 Z)-7(\mathrm{X}=\mathrm{O} ; \mathrm{Y}=\mathrm{O})$ & OEt & $=\mathrm{CHCOOEt}$ & $\mathrm{H}$ & 5.64 & 149.9 & 93.1 & 56.8 \\
\hline 10 & $(Z)-8 \mathbf{a}(\mathrm{X}=\mathrm{S} ; \mathrm{Y}=\mathrm{O})$ & $\mathrm{Ph}$ & $\mathrm{CH}_{3}$ & $\mathrm{H}$ & 7.58 & 166.0 & 111.6 & 54.4 \\
\hline 11 & $(Z)-8 b(X=S ; Y=O)$ & $\mathrm{Ph}$ & $\mathrm{CH}_{2} \mathrm{COOEt}$ & $\mathrm{CH}_{3}$ & 7.43 & 162.8 & 112.0 & 50.8 \\
\hline 12 & $(Z)-8 \mathrm{c}(\mathrm{X}=\mathrm{S} ; \mathrm{Y}=\mathrm{S})$ & $\mathrm{Ph}$ & $\mathrm{CH}_{2} \mathrm{COOEt}$ & $\mathrm{CH}_{3}$ & 7.61 & 164.9 & 113.9 & 51.1 \\
\hline 13 & $(Z)-9 \mathbf{a}(\mathrm{X}=\mathrm{S} ; \mathrm{Y}=\mathrm{O})$ & $\mathrm{NH}_{2}$ & $\mathrm{CH}_{2} \mathrm{COOEt}$ & $\mathrm{H}$ & 6.15 & 156.9 & 100.8 & 56.1 \\
\hline 14 & $(E)-9 \mathrm{a}(\mathrm{X}=\mathrm{S} ; \mathrm{Y}=\mathrm{O})$ & $\mathrm{NH}_{2}$ & $\mathrm{CH}_{2} \mathrm{COOEt}$ & $\mathrm{H}$ & 5.64 & 154.9 & 97.2 & 57.6 \\
\hline 15 & $(Z)-9 b(X=S ; Y=O)$ & $\mathrm{NH}_{2}$ & $\mathrm{H}$ & $\mathrm{H}$ & 6.16 & 158.4 & 100.2 & 58.2 \\
\hline 16 & $(Z)-9 \mathrm{c}(\mathrm{X}=\mathrm{S} ; \mathrm{Y}=\mathrm{O})$ & $\mathrm{NH}(\mathrm{CH})_{2} \mathrm{Ph}$ & $\mathrm{H}$ & $\mathrm{H}$ & 6.21 & 156.1 & 101.2 & 54.9 \\
\hline 17 & $(E)-9 \mathrm{c}(\mathrm{X}=\mathrm{S} ; \mathrm{Y}=\mathrm{O})$ & $\mathrm{NH}(\mathrm{CH})_{2} \mathrm{Ph}$ & $\mathrm{H}$ & $\mathrm{H}$ & 5.64 & - & - & - \\
\hline
\end{tabular}

9a-c (5.64-6.21 ppm) and enaminoesters 1f-g and 7 (5.44-5.64 ppm), despite the expected $\mathrm{CO}(\mathrm{S}) \mathrm{Ph}>\mathrm{CO}(\mathrm{S}) \mathrm{NHR} / \mathrm{CO}_{2} \mathrm{R}$ order of electron withdrawing power of the substituent $\mathrm{R}_{1} \mathrm{CO}(\mathrm{S}) .{ }^{10 i}$ In addition, the $\mathrm{C}\left(2^{\prime}\right)-H$ signals of compounds containing the $\mathrm{R}_{1} \mathrm{CS}$ substituent are found at a lower field than the signals of compounds that have the $\mathrm{R}_{1} \mathrm{CO}$ group $(\delta 7.43-7.61 / 6.78-6.95 \mathrm{ppm}$ for enamino thioketones 8a-c/enamino ketones 1a-c, $\delta$ 5.646.21/5.36-5.79 ppm for enamino thioamides 9a-c/enamino amides 1d-e), and thus predict the wrong order of electron accepting ability of the carbonyl and thiocarbonyl groups. Likewise, the ${ }^{13} \mathrm{C}$ NMR chemical shift differences $\Delta \delta_{\mathrm{C}(2)}=\mathrm{C}\left(2^{\prime}\right)$ point to the stronger electron withdrawing ability of $\mathrm{R}_{1} \mathrm{CO}$ $\left(\Delta \delta_{\mathrm{C}(2)}=\mathrm{C}\left(2^{\prime}\right)=59.2-70.6 \mathrm{ppm}\right)$ with respect to that of $\mathrm{R}_{1} \mathrm{CS}$ $\left(\Delta \delta_{\mathrm{C}(2)}=\mathrm{C}\left(2^{\prime}\right)=50.8-58.2 \mathrm{ppm}\right)$, and also predict thioamides 9a-c $\left(\Delta \delta_{\mathrm{C}(2)}=\mathrm{C}\left(2^{\prime}\right)=54.9-58.2 \mathrm{ppm}\right)$ to show a larger push-pull effect than thioketones 8a-c $\left(\Delta \delta_{\mathrm{C}(2)}=\mathrm{C}\left(2^{\prime}\right)=50.8-54.4 \mathrm{ppm}\right)$. This is more evident when related systems are compared. Thus, for example, values for ketone $(Z)-\mathbf{1 a}$ and thioketone $(Z)-\mathbf{8 a}$, differing only in $\mathrm{O} / \mathrm{S}$ contained in the EWG substituent, are as follows: $\mathrm{C}\left(2^{\prime}\right)-H$ at $\delta 6.80 \mathrm{ppm}$ and $7.58 \mathrm{ppm}$, respectively, and $\Delta \delta_{\mathrm{C}(2)=\mathrm{C}\left(2^{\prime}\right)} 66.1 \mathrm{ppm}$ and $54.40 \mathrm{ppm}$, respectively. The inability of proton chemical shifts to correctly reproduce the trend in the strength of the push-pull effect is easily rationalized by their high sensitivity to proton environment (solvent effect, anisotropic effects from substituents). Obviously, the ${ }^{13} \mathrm{C}$ NMR chemical shifts of the two carbon atoms in the double bond are influenced not only by the strength of the push-pull effect, but by other factors too. Among them, influences coming from substituents directly attached to the double bond are the most prominent ones. For example, the stronger (-I) effect of the $\mathrm{R}_{1} \mathrm{CX}$ substituent in oxygen analogues $(\mathrm{X}=\mathrm{O})$ than in sulfur ones $(\mathrm{X}=\mathrm{S}$ ) could be a reasonable explanation of the opposite trend of the $\Delta \delta_{\mathrm{C}(2)=\mathrm{C}\left(2^{\prime}\right)}$ values observed for these compounds.
However, when comparing the push-pull effect of thiazolidine enaminoesters $(Z)-\mathbf{1 f},(Z)-\mathbf{1 g}$ and $(2 E, 5 Z)-7$, with different substituents at the $\mathrm{C}(5)$ position and the same ones at the double bond, both the $\mathrm{C}\left(2^{\prime}\right)-H$ chemical shifts $(5.44 / 5.63 \mathrm{ppm}$ for $\mathbf{1 f}$, $\mathbf{1 g} / 7)$ and the $\Delta \delta_{\mathrm{C}(2)=\mathrm{C}\left(2^{\prime}\right)}$ parameters (69-70.6/56.8 ppm for 1f, $1 \mathrm{~g} / 7)$ correctly indicate a lowering of the push-pull effect associated with the electron withdrawing effect of the $\mathrm{C}(5)=\mathrm{C}\left(5^{\prime}\right) \mathrm{CO}_{2} \mathrm{Et}$ substituent in $7 .^{11}$ The $\mathrm{C}\left(2^{\prime}\right)-H$ chemical shifts, as well as $\Delta \delta_{\mathrm{C}(2)=\mathrm{C}\left(2^{\prime}\right)}$ also correctly represent a slightly increased pushpull effect for intramolecularly hydrogen bonded $E$ isomers with respect to the $Z$ ones. ${ }^{10 i}$ For example, $\mathrm{C}\left(2^{\prime}\right)-H$ protons of $(E)-1 d$ and $(E)-9 a$ resonate at a higher field than the $\mathrm{C}\left(2^{\prime}\right)-H$ protons of $(Z)-\mathbf{1 d}$ and $(Z)-9 a$, while $\Delta \delta_{\mathrm{C}(2)=\mathrm{C}\left(2^{\prime}\right)}$ is larger for the $E$ isomer of 9a (entries 4 and 5,13 and 14). The same is true for the $\mathrm{C}\left(2^{\prime}\right)-H$ chemical shifts of derivatives $(Z)-8 \mathbf{b}(\delta 7.43 \mathrm{ppm})$ and $(Z)-8 \mathrm{c}(\delta 7.61 \mathrm{ppm})$, which correctly indicate a drop in the push-pull character due to the replacement of the ring carbonyl group in $\mathbf{8 b}$ by a thiocarbonyl group in 8c. The $\Delta \delta_{\mathrm{C}(2)=\mathrm{C}\left(2^{\prime}\right)}$, however, does not show the same trend.

Despite the above mentioned limitations of the quantification of the push-pull effect, the $\Delta \delta_{\mathrm{C}(2)=\mathrm{C}\left(2^{\prime}\right)}$ values strongly suggest that the structure of 2-alkylidene-4-oxothiazolidines can be described by the hybrid structure $\mathbf{F}$ as an equivalent of the general dipole type structure I of the push-pull alkenes presented in Scheme 2. We also wish to note that the full zwitterionic structure has been confirmed experimentally by very low temperature X-ray diffraction analysis of 3-(1,3-diisopropyl-2-imidazolidinylidene)2,4-pentanedione. ${ }^{24}$

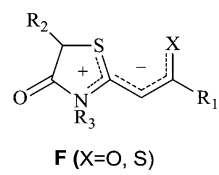




\subsection{Stereodynamic behaviour of 2-alkylidene-4- oxothiazolidine derivatives}

Over the past few decades, investigations into the static and dynamic stereochemistry of push-pull alkenes published up to 1983 have been reviewed by Sandström ${ }^{10} a$ and recently by Kleinpeter et al. ${ }^{10 c, e}$ who showed that donor-acceptor electronic interactions occurring via the $\mathrm{C}=\mathrm{C}$ double bond (resonance structures B-E and hybrid structure $\mathbf{I}$ in Scheme 2; resonance structure $\mathbf{D}$ and hybrid structure $\mathbf{G}$ in Scheme 3) are the main factor responsible for the lowering of the rotational barrier around the $\mathrm{C}=\mathrm{C}$ bond. Recent theoretical studies ${ }^{10 c, i}$ have found that in a fragment shown in Scheme 3, these electronic interactions increase in the order: $\mathrm{O}<\mathrm{S}$.

In the case of our stereodefined push-pull thiazolidine derivatives 1 (Scheme 1), the above mentioned electronic interactions, that occur here between two electron donors ( $\mathrm{N}_{\text {ring }}$ and $\left.\mathrm{S}_{\text {ring }}\right)$ and one electron acceptor $\left(\mathrm{R}_{1} \mathrm{CX} ; \mathrm{R}_{1}=\mathrm{Ph}\right.$, OEt, $\mathrm{NHPh}, \mathrm{NH}\left(\mathrm{CH}_{2}\right)_{2} \mathrm{Ph}$; $\mathrm{X}=\mathrm{O}$ ), have been evidenced by the facile $Z / E$ configurational isomerization that takes place spontaneously in solution, at room temperature (Scheme 4). ${ }^{11,13}$ The direction of this isomerization is dictated by solvent polarity. Polar solvents break the intramolecular hydrogen bonding in the $E$ isomer and shift the equilibrium to the $Z$ isomer, by forming stable solventsolute intermolecular interactions. On the other hand, in nonpolar solvents, the intramolecularly hydrogen bonded $E$ isomer becomes the dominant species (Scheme 4).

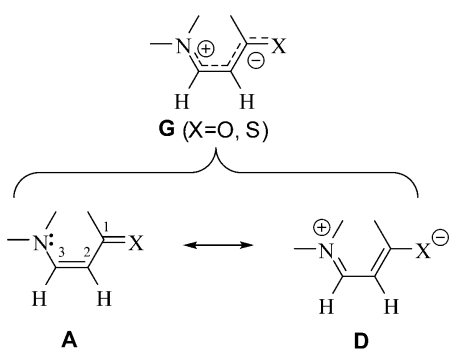

Scheme 3 The push-pull effect of vinylogous amides and thioamides $(X=O, S)$.

\subsection{Kinetic and thermodynamic aspects of configurational isomerization}

To extend our knowledge on the solvent dependent $Z / E$ configurational equilibrium of 2-alkylidene-4-oxothiazolidines and the strength of their push-pull character, we studied the isomerization of (E)-(5-ethoxycarbonylmethyl-4-oxothiazolidin-2-ylidene)ethanthioamide $(E)-\mathbf{9 a}$. For this purpose, variable temperature NMR determination of the dynamics of the configurational isomerism was done in DMSO- $d_{6}$ (Fig. 4), as well as studies of the rotational barrier $\Delta G^{\ddagger}$ around the $\mathrm{C}(2)=\mathrm{C}\left(2^{\prime}\right)$ bond (Table 3). In Table 3 are also included the values for the other two activation parameters $\Delta H^{\ddagger}$ and $\Delta S^{\ddagger}$, the data for the two Arrhenius parameters (apparent activation energy $E_{\mathrm{a}}$ and frequency factor $A$ ), the overall rate constant $k$ and the equilibrium constant $K^{\ddagger}$ between the TS and GS. The results are compared with those for $(Z)-\mathbf{1 b}$ determined in $\mathrm{CDCl}_{3}$ (Scheme $5 \mathrm{~A}$ ) and $(2 E, 5 Z)-7$ determined in DMSO- $d_{6}$ (Scheme $5 \mathrm{~B}$ ), previously reported by us. ${ }^{11}$

The mechanism of the $(E)-\mathbf{9 a} \rightleftharpoons(Z)-\mathbf{9 a}$ isomerization can be proposed as follows:

$$
\mathrm{B} \underset{k_{-1}}{\stackrel{k_{1}}{\Leftrightarrow}} \mathrm{B}^{*} \stackrel{k_{2}}{\longrightarrow} \mathrm{C}
$$

On the basis of the steady state approximation and assuming that $k_{-1}<k_{1}$, the reaction is further approximated to a first order reaction. The overall rate constant, $k$, is determined as the slope of the best straight line fitted through ten points, when $\ln \left[B / B_{0}\right]$ is plotted against time $(t)$. The slope of the Arrhenius plot gives the apparent energy of activation and the intercept at $1 / T=0$ yields the frequency factor $A$ (Fig. S7 in the ESI; $\dagger$ Table 3 ). Additionally, the $\Delta H^{\ddagger}$ and $\Delta S^{\ddagger}$ values were evaluated using the Eyring equation by plotting $\ln k / T$ versus $1 / T$ and, as a result, the free energy of activation was calculated to be $96.5 \mathrm{~kJ} \mathrm{~mol}^{-1}$ (Fig. S8 in the ESI; $\dagger$ Table 3$)$. Thus, for the $(E)-9 \mathbf{a} \rightleftharpoons(Z)-9 \mathbf{a}$ transformation, first order kinetics has been established.

The magnitudes of $\Delta H^{\ddagger}$ and $\Delta S^{\ddagger}$ represent the differences in enthalpy and entropy between transition and ground state structures. During configurational isomerization, enthalpy increases and on reaching the transition state becomes equal to $\Delta H^{\ddagger}$,<smiles>[R]C(=[X])/C=C1\NC(=O)C([R])S1</smiles>

(Z)-isomer (A) dominant in polar solvents<smiles>[Y]C([Z])=CC1=NC(=O)C([R])S1</smiles>

(Z)-D1<smiles>[Z]C([Y])=CC1=[S+]C([R])C(=O)N1</smiles>

(Z)-D2<smiles></smiles>

$(E)$-D2<smiles>[Y]C([R])=CC1=NC(=O)C([R])S1</smiles>

$(E)-\mathrm{D} 1$ 


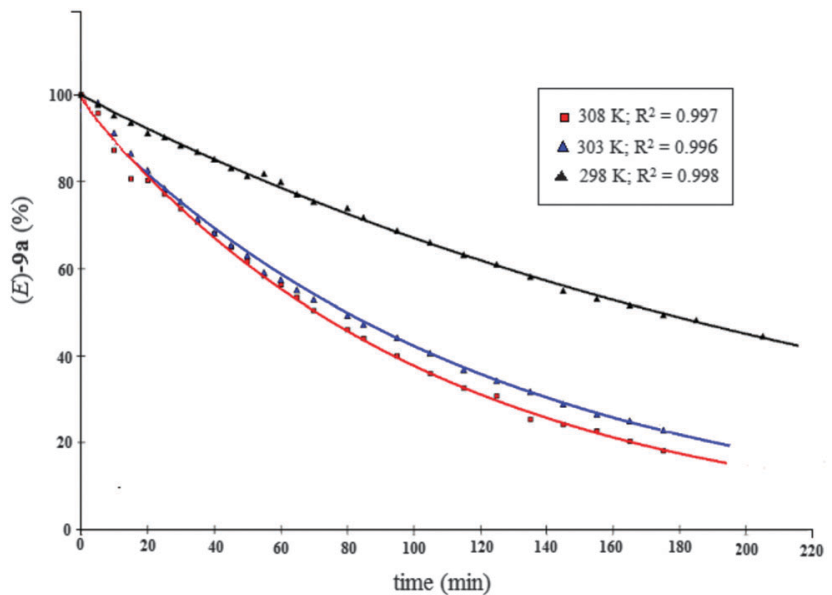

Fig. 4 Plot of $E / Z$ ratio versus reaction time for thiazolidine derivative 9a determined at 298, 303 and $308 \mathrm{~K}$.

when the $\mathrm{C}(2)=\mathrm{C}\left(2^{\prime}\right)$ double bond is broken. As the data in Table 3 show, the activation enthalpies span a range from $39.3 \mathrm{~kJ} \mathrm{~mol}^{-1}$ (1) to $80.9 \mathrm{~kJ} \mathrm{~mol}^{-1}$ (7) and are endothermic. These values are influenced by structural changes within the molecule and by the solvent. Generally, solvents decrease $\Delta H^{\ddagger}$ values because the more polar TS (due to the full charge separation) is more solvated than the less polar GS. On the other hand, $\Delta S^{\ddagger}$, measuring the degree of ordering, can be negative or positive if translational, vibrational, or rotational degrees of freedom are lost or gained on moving to the transition state. The negative $\Delta S^{\ddagger}$ values determined for the isomerization of $(Z)-\mathbf{1 b},(2 E, 5 Z)-\mathbf{7}$ and $(E)-9$ a indicate an increased ordering when the molecule reaches a transition state, more prominent for $\mathbf{1 b}$ and $\mathbf{9 a}$, than for $\mathbf{7}$. A part of it has to be ascribed to increased ordering in a solvent (mostly those molecules directly interacting with the solute) so to make $\Delta H^{\ddagger}$ more favourable (less positive). The resulting $\Delta G^{\ddagger}$, spanning a rather narrow range of $3.6 \mathrm{~kJ} \mathrm{~mol}^{-1}$, concurs with our previous estimation of the electron withdrawing ability of substituents as $\mathrm{CSNH}_{2}>\mathrm{COPh}>\mathrm{CO}_{2}$ Et. $^{10 i}$ Although this correct trend may perhaps not be reproduced under different experimental conditions, since rotational barriers depend on the direction of isomerization $(E \rightarrow Z$ or $Z \rightarrow E)$ and the solvent, the following results strongly support it.

Thus, if we compare $E \rightarrow Z$ isomerization of 7 and $9 \mathrm{a}$ in the same solvent (DMSO- $d_{6}$ ) and at the same temperature (298 K), all activation parameters $E_{\mathrm{a}}, \Delta H^{\ddagger}$ and $\Delta G^{\ddagger}$ indicate a decreased push-pull character in 7 , related to both the electronic properties of the EWG and additional barrier-increasing effect of the $\mathrm{C}(5)=\mathrm{C}\left(5^{\prime}\right) \mathrm{CO}_{2}$ Et moiety. The isomerization rate is 4.3 times faster for 9a than for 7 and 2.2 times faster than that determined for $\mathbf{1 b}$ in $\mathrm{CDCl}_{3}$, as can be seen from the rate constants $k$.

The two related quantities, $E_{\mathrm{a}}$ and $\Delta H^{\ddagger}$, show a somewhat different trend, that is, a reversed order of electron accepting ability of keto and thioamide substituents: $\mathrm{COPh}>\mathrm{CSNH}_{2}$, corresponding to the easier isomerization of $\mathbf{1 b}$ with respect to 9a. This could be attributed to the solvent polarity $\left(\mathrm{CDCl}_{3}\right.$ in the case of $\mathbf{1 b}$ instead of DMSO- $d_{6}$ for $\mathbf{9 a}$ ) and direction of isomerization $(Z \rightarrow E$ for $\mathbf{1 b}$ instead of $E \rightarrow Z$ in the case of $\mathbf{9 a}$ ). Therefore, the change from $\mathrm{CDCl}_{3}$ to the more polar DMSO- $d_{6}$ and the opposite isomerization direction would possibly increase both $E_{\mathrm{a}}$ and $\Delta H^{\ddagger}$, and show the correct trend in electron-accepting ability of substituents for these compounds. As we were unable to isolate the $E$ isomer of $\mathbf{1 b}$, this was checked by computation of $\Delta H^{\ddagger}$ and $\Delta G^{\ddagger}$ in DMSO for the $E \rightarrow Z$ direction for all three compounds, as shown in Table 4. The table also includes calculated barrier energies for the $Z \rightarrow E$ isomerization in $\mathrm{CHCl}_{3}$. All calculated values show the correct trend in decreasing rotational barriers: $\mathbf{7}>\mathbf{1 b}>\mathbf{9 a}$. This also means that the push-pull effect is not affected by the solvent (at least the two solvents studied) and the direction of isomerization. The observation that calculated $\Delta H^{\ddagger}$ and $\Delta G^{\ddagger}$ are almost identical (entries 1-3), or differ slightly (entries 5 and 6), supports our explanation that the experimentally obtained negative entropy values (Table 3) can be associated with the ordering of solvent molecules, which is not taken into account in computations.

Thus, we offer the following explanation for the observed deviation of experimental $\Delta H^{*}$ in the case of $Z \rightarrow E$ isomerization of $\mathbf{1 b}$ in $\mathrm{CDCl}_{3}$ and its most negative $\Delta S^{\ddagger}$ (Table 3, entry 4). First, we have to recall that the TS is more polar than the GS due to larger charge polarization. Thus, the studied isomerization of $\mathbf{1 b}$ requires a higher ordering in the weakly polar $\mathrm{CDCl}_{3}$ molecules at the moment the TS is reached, so as to stabilize the TS as efficiently as possible. This reduces both $\Delta S^{\ddagger}$ and $\Delta H^{\ddagger}$. By contrast, polar DMSO- $d_{6}$ stabilizes TS with less molecular ordering, resulting in lower absolute entropy values.

\subsection{Computational approach for studying rotational barriers and their relation to the push-pull effect}

3.5.1. Ground state and transition state structures of studied 2-alkylidene-4-oxothiazolidines. The GS and TS structures of 7 are presented in Fig. 5, and of all other compounds in Fig. S9 in the ESI. $\dagger$ In the ground state of both $Z$ and $E$ isomers, the 4-oxothiazolidine ring and exocyclic carbon atom of the double bond with its $\mathrm{C}=\mathrm{X}$ substituent are in the same plane. When the $\mathrm{R}_{1}$ part of $\mathrm{R}_{1} \mathrm{CX}$ is NHPh (1d), OEt $(\mathbf{1 g})$ and $\mathrm{NH}_{2}(\mathbf{9 a})$, the whole EWG is in plane with the ring. When $\mathrm{R}_{1}=\mathrm{Ph}$, as in

Table 3 Apparent activation energy $\left(E_{\mathrm{a}}\right)$, frequency factor $(A)$, overall rate constant $(k)$, TS/GS equilibrium constant $\left(K^{\star}\right)$ and activation parameters $\left(\Delta H^{\ddagger}\right.$, $\Delta S^{\ddagger}$ and $\left.\Delta G^{\ddagger}\right)$ for rotation around the $C(2)=C\left(2^{\prime}\right)$ double bond in 4-oxothiazolidines $(Z)-1 \mathbf{b},(2 E, 5 Z)-7$ and $(E)-9$ a

\begin{tabular}{|c|c|c|c|c|c|c|c|c|c|c|}
\hline Entry & Compound & Solvent & $T[\mathrm{~K}]$ & $E_{\mathrm{a}}\left[\mathrm{kJ} \mathrm{mol}^{-1}\right]$ & $\ln A\left[\mathrm{~s}^{-1}\right]$ & $k\left[\mathrm{~s}^{-1}\right]$ & $\Delta H^{\ddagger}\left[\mathrm{kJ} \mathrm{mol}^{-1}\right]$ & $\Delta S^{\ddagger}\left[\mathrm{J} \mathrm{mol}^{-1} \mathrm{~K}^{-1}\right]$ & $\Delta G^{\ddagger}\left[\mathrm{kJ} \mathrm{mol}^{-1}\right]$ & $K^{\ddagger}$ \\
\hline 2 & $(E)-9 \mathbf{a}$ & DMSO- $d_{6}$ & 303 & 60.3 & 14.80 & $1.11 \times 10^{-4}$ & 57.4 & -131.2 & 96.5 & $1.76 \times 10^{-17}$ \\
\hline 3 & $(E)-9 \mathbf{a}$ & DMSO- $d_{6}$ & 308 & 60.3 & 14.80 & $1.60 \times 10^{-4}$ & 57.4 & -131.2 & 96.5 & $2.50 \times 10^{-17}$ \\
\hline 5 & $(2 E, 5 Z)-7$ & DMSO- $d_{6}$ & 298 & 83.3 & 22.74 & $1.70 \times 10^{-5}$ & 80.9 & -64.7 & 100.2 & $2.74 \times 10^{-18}$ \\
\hline
\end{tabular}


A

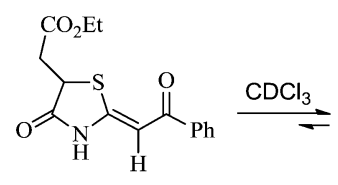

(Z)-1b

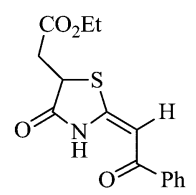

$(E)-\mathbf{1 b}$
B

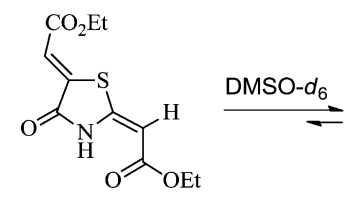

$(2 E, 5 Z)-7$

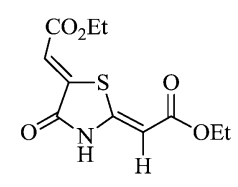

$(2 Z, 5 Z)-7$

Scheme 5 Configurational isomerization of (Z)-1b and (2E,5Z)-7 thiazolidine derivatives.

Table 4 Calculated values of $H^{*}$ and $\Delta G^{\ddagger}$ conducted at the M06-2X/ 6-311G** level of theory (in $\mathrm{kJ} \mathrm{mol}^{-1}$ ) for $E \rightarrow Z$ isomerization of $\mathbf{1 b}, \mathbf{7}$ and $\mathbf{9 a}$ in $\mathrm{DMSO}$, and for $Z \rightarrow E$ isomerization in $\mathrm{CHCl}_{3}$

\begin{tabular}{lllll}
\hline Entry & Compound & Solvent & $\Delta H^{\ddagger}\left[\mathrm{kJ} \mathrm{mol}^{-1}\right]$ & $\Delta G^{\ddagger}\left[\mathrm{kJ} \mathrm{mol}^{-1}\right]$ \\
\hline 1 & $\mathbf{1 b}$ & DMSO & 147.0 & 146.4 \\
2 & $\mathbf{1 b}$ & CHCl $_{3}$ & 155.1 & 154.4 \\
3 & 7 & DMSO & 168.5 & 169.1 \\
4 & 7 & CHCl $_{3}$ & 167.3 & 173.4 \\
5 & 9a & DMSO & 132.5 & 134.1 \\
6 & 9a & CHCl $_{3}$ & 129.7 & 132.7 \\
\hline
\end{tabular}

1b $\left(\mathrm{R}_{1} \mathrm{CX}=\mathrm{COPh}\right)$ and $\mathbf{8 a}\left(\mathrm{R}_{1} \mathrm{CX}=\mathrm{CSPh}\right)$, the fully planar thiazolidine/double bond/CO(S) moiety and the phenyl ring form angles of $\sim 16^{\circ}$ and $\sim 40^{\circ}$, respectively, due to steric hindrance between the $\mathrm{Ph}$ and the $\mathrm{CX}$ part. In the case of $\mathrm{R}_{1}=\mathrm{NH}\left(\mathrm{CH}_{2}\right)_{2} \mathrm{Ph}$, a fully planar structure was obtained for $9 \mathrm{c}\left(\mathrm{R}_{1} \mathrm{CX}=\mathrm{CSNH}\left(\mathrm{CH}_{2}\right)_{2} \mathrm{Ph}\right)$. However, in the case of $1 \mathrm{e}\left(\mathrm{R}_{1} \mathrm{CX}=\mathrm{CONH}\left(\mathrm{CH}_{2}\right)_{2} \mathrm{Ph}\right)$, the conformation around the $\mathrm{H}_{2} \mathrm{CH}_{2} \mathrm{C}-\mathrm{C}_{\mathrm{Ar}}$ bond is such that the phenyl ring and the neighbouring $\mathrm{C}-\mathrm{C}$ bond form an angle of $\sim 80^{\circ}$. The $\mathrm{C}(5)$ substituent $\left(\mathrm{CH}_{2} \mathrm{CO}_{2} \mathrm{Et}\right)$ is out of plane when attached to the $\mathrm{sp}^{3}$-hybridized carbon atom. In the case of 7 , possessing another exocyclic $\mathrm{C}=\mathrm{C}$ double bond at the $\mathrm{C}(5)$ position, the structure is fully planar (Fig. 5).

In the transition state structures, the thiazolidine ring as the donor part and the acceptor moiety are nearly perpendicular to each other. The $\mathrm{C}(2) \mathrm{C}\left(2^{\prime}\right)$ bond is elongated, becoming a single bond in TS, while the $\mathrm{C}(2)-\mathrm{S}_{\text {ring }}, \mathrm{C}(2)-\mathrm{N}_{\text {ring }}$ and $\mathrm{C}\left(2^{\prime}\right)-\mathrm{C}$ bonds are shortened. Calculated $\mathrm{C}(2) \mathrm{C}\left(2^{\prime}\right)$ bond lengths in GS and TS are given in Table 5 .

3.5.2. Calculated barriers to rotation as a means to quantify the push-pull effect in 2-alkylidene-4-oxothiazolidines. The gas phase calculated $\Delta H^{\ddagger}$ and $\Delta G^{\ddagger}$ values for the $E \rightarrow Z$ and $Z \rightarrow E$ isomerizations of selected thiazolidine derivatives do not differ by more than $7 \mathrm{~kJ} \mathrm{~mol}^{-1}$ and they show the same trend. Thus, only $\Delta G^{\ddagger}$ values are presented in Table 5 , along with the calculated $\mathrm{C}(2)=\mathrm{C}\left(2^{\prime}\right)$ bond lengths in the ground and transition state structures. The barriers span a broad range of $\sim 144 \mathrm{~kJ} \mathrm{~mol}^{-1}$, being the lowest for $\mathbf{8 a}$ and the highest for 7 (entries 5 and 6). It is evident that $E \rightarrow Z$ isomerizations encounter higher barriers than the reverse $Z \rightarrow E$ isomerizations. This is easily rationalized by the lower energy of $E$ isomers due to their stabilization by intramolecular hydrogen bonding, which exceeds that coming from non-bonded $1,5-\mathrm{S}_{\text {ring }} \cdots \mathrm{O}(\mathrm{S})_{\text {substituent }}$ interactions. On the basis of the data in Table $5, \mathrm{R}_{1} \mathrm{CX}$ substituents can be ordered according to their electron accepting ability as follows: $\mathrm{CSPh}>\mathrm{CSNH}_{2} \approx \mathrm{CSNHCH}_{2} \mathrm{CH}_{2} \mathrm{Ph}>\mathrm{COPh}>\mathrm{CO}_{2} \mathrm{Et}>$ $\mathrm{CONH}\left(\mathrm{CH}_{2}\right)_{2} \mathrm{Ph}>\mathrm{CONHPh}$. The obtained trend is in agreement with our understanding of the electronic properties of substituents and also concurs with our previously reported trend, which was established on the basis of occupation quotient values. $^{10 i, 25}$ The data in Table 5 show that the remote substituent effect (compound 7) places the barrier to be the highest. The barrier in 7 is affected by two effects, acting in opposite directions: the $\mathrm{C}\left(2^{\prime}\right)$ ester group withdraws $\pi$ electrons from the $\mathrm{C}(2)=\mathrm{C}\left(2^{\prime}\right)$ double bond and decreases the barrier, while the $\mathrm{C}(5)=\mathrm{C}\left(5^{\prime}\right) \mathrm{CO}_{2}$ Et moiety withdraws electron density from the ring sulfur atom, thus reducing its ability to donate a lone pair to the $\mathrm{C}(2)=\mathrm{C}\left(2^{\prime}\right)$ double bond which increases the barrier.

In our previous work, we have shown that the two parameters, that is, the occupation quotient and the $\mathrm{C}(2)=\mathrm{C}\left(2^{\prime}\right)$ bond length in 2-alkylidene-4-oxothiazolidines, show a good linear correlation, ${ }^{10 i}$ which means that they can be considered reliable for quantification of the push-pull effect. Therefore, we correlated the calculated barriers to rotation with the $\mathrm{C}=\mathrm{C}$ bond lengths of the ground state structures, as shown in Fig. 6 . A good linear correlation, obtained for both isomerization directions, indicates that the magnitudes of rotational barriers reflect changes in the strength of the push-pull effect in the studied compounds. An important observation is that their relative order is not affected by hydrogen bonding stabilization in $E$ isomers and $1,5-S_{\text {ring }} \cdots \mathrm{O}(\mathrm{S})_{\text {substituent interactions present }}$ in $Z$ isomers. Thus, this quantity can be regarded as a reliable measure of the push-pull effect in the studied, and possibly in related heterocycles, as well.

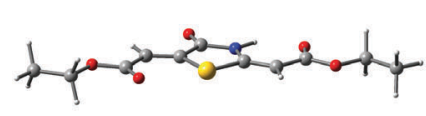

(2E,5Z)-7

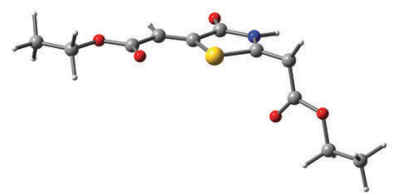

TS-7

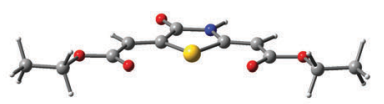

$(2 Z, 5 Z)-7$

Fig. 5 Optimized GS and TS structures of compound 7. 
Table 5 Calculated $\mathrm{C}(2) \mathrm{C}\left(2^{\prime}\right)$ bond lengths $(\AA)$ in $\mathrm{GS}$ and TS and barriers to rotation $\left(\Delta G^{\ddagger}, \mathrm{kJ} \mathrm{mol}^{-1}\right)$ around the $\mathrm{C}=\mathrm{C}$ double bond for the studied thiazolidine derivatives

\begin{tabular}{|c|c|c|c|c|c|c|c|c|}
\hline \multirow[b]{2}{*}{ Entry } & \multirow[b]{2}{*}{ Compound } & \multirow[b]{2}{*}{$\mathrm{R}_{1}$} & \multirow[b]{2}{*}{$\mathrm{R}_{2}$} & \multicolumn{2}{|l|}{$\Delta G^{\ddagger}$} & \multicolumn{2}{|l|}{$\underline{d_{\mathrm{C}=\mathrm{C}}(\mathrm{GS})}$} & \multirow[b]{2}{*}{$d_{\mathrm{C}-\mathrm{C}}(\mathrm{TS})$} \\
\hline & & & & $Z \rightarrow E$ & $E \rightarrow Z$ & $E$ isomer & $Z$ isomer & \\
\hline 4 & $1 \mathrm{~g}(\mathrm{X}=\mathrm{O})$ & OEt & $\mathrm{CH}_{2} \mathrm{COOEt}$ & 175.8 & 187.6 & 1.349 & 1.347 & 1.428 \\
\hline 5 & $7(\mathrm{X}=0)$ & OEt & $=\mathrm{CHCOOEt}$ & 207.9 & 221.6 & 1.347 & 1.344 & 1.424 \\
\hline 6 & $8 \mathbf{a}(X=S)$ & $\mathrm{Ph}$ & $\mathrm{CH}_{3}$ & 64.5 & 77.8 & 1.366 & 1.363 & 1.503 \\
\hline 7 & $9 a(X=S)$ & $\mathrm{NH}_{2}$ & $\mathrm{CH}_{2} \mathrm{COOEt}$ & 128.6 & 147.8 & 1.355 & 1.354 & 1.445 \\
\hline 8 & $9 c(X=S)$ & $\mathrm{NH}(\mathrm{CH})_{2} \mathrm{Ph}$ & $\mathrm{H}$ & 129.5 & 146.3 & 1.353 & 1.352 & 1.440 \\
\hline
\end{tabular}

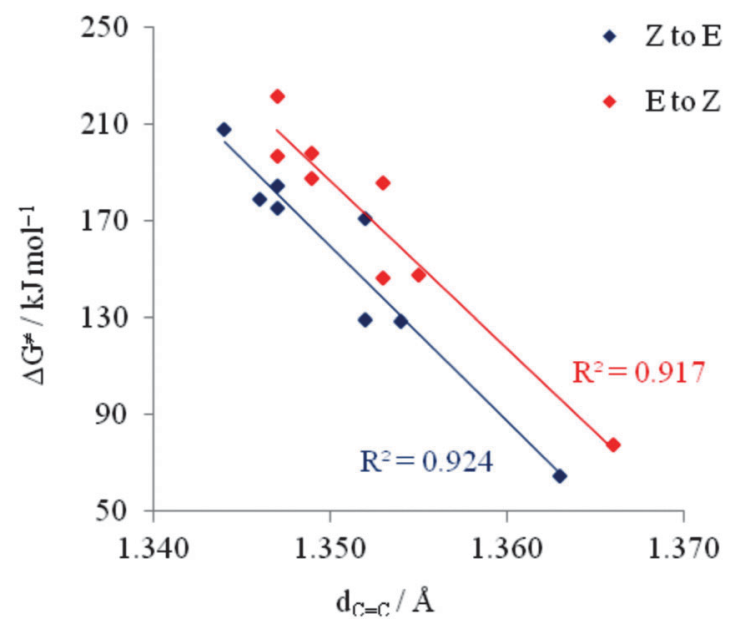

Fig. 6 Correlation between the calculated barriers to rotation $\left(\Delta G^{\ddagger}\right)$ and the $\mathrm{C}=\mathrm{C}$ bond lengths of GS structures.

\section{Conclusions}

Bearing in mind the importance of knowledge about the strength of the push-pull effect in push-pull alkenes, we have examined the reliability of NMR spectroscopic data and barriers to rotation around the $\mathrm{C}=\mathrm{C}$ double bond to provide information about the push-pull character in the case of biologically important 2-alkylidene-4-oxothiazolidine derivatives with various electron withdrawing groups at the $\mathrm{C}\left(2^{\prime}\right)$ position. Due to the larger sensitivity of the olefinic ${ }^{1} \mathrm{H}$ NMR chemical shifts to proton environmental effects (substituent anisotropic effects being the most pronounced) than to changes in the push-pull effect, these data fail to show the correct trend in electron withdrawing ability of the substituents. Although, the large ${ }^{13} \mathrm{C}$ NMR chemical shift differences between the two carbon atoms contained in the $\mathrm{C}=\mathrm{C}$ double bond are indicative of a significant charge polarization within the bond, this NMR parameter shows sensitivity not only to the electron-withdrawing power of the substituents but to other factors also. Therefore, NMR chemical shifts do not provide a reliable picture of the strength of push-pull character.
On the other hand, the experimentally determined and the gas-phase calculated rotational barriers show the correct order of acceptor substituents with respect to their electron accepting ability, which was not affected by ground state influences such as intramolecular hydrogen bonding and non-bonded 1,5-S $\cdots \mathrm{O}(\mathrm{S})$ interactions. The calculated barriers also show a good correlation with $\mathrm{C}=\mathrm{C}$ bond lengths, which have been proven previously to provide reliable information about the strength of the push-pull effect in related thiazolidine systems. Thus, the relative magnitudes of barriers to rotation can give us information about the changes in the push-pull character of studied and related compounds. The subtle effects coming from a remote group were reflected in the barrier values, too.

The importance of the computational results also lies in the fact that rotational barriers are not always experimentally accessible, as in cases when the isomerization rate falls beyond the timescale of an NMR experiment or when the double bond is part of a ring.

The fact that the continuum solvation COSMO model used for the solution-state calculations was not able to reproduce the large negative activation entropy observed in experiments, supported our assumption that the sign and the value of experimental $\Delta S^{\ddagger}$ reflects an increased ordering of solvent molecules as a transition state is reached, rather than ordering within the solute molecules.

\section{Acknowledgements}

This work was supported by the Ministry of Education, Science and Technological Development of the Republic of Serbia (project ID: 172020).

\section{References}

1 (a) F. C. Brown, Chem. Rev., 1961, 61, 463-521; (b) G. Newcome, Adv. Heterocycl. Chem., 1979, 25, 83-112; (c) S. P. Singh, S. S. Parmar, K. Raman and V. I. Stenberg, Chem. Rev., 1981, 81, 175-203; (d) R. B. Lesyk and B. S. Zimenkovsky, Curr. Org. Chem., 2004, 8, 1547-1577; (e) W. Cunico, C. R. B. Gomes and 
W. T. Vellasco, Jr., Mini-Rev. Org. Chem., 2008, 5, 336-344; $(f)$ W. S. Hamama, M. A. Ismail, S. Shaaban and H. H. Zoorob, J. Heterocycl. Chem., 2008, 45, 939-956; $(g)$ A. Verma and S. K. Saraf, Eur. J. Med. Chem., 2008, 43, 897-905; (h) A. K. Jain, A. Vaidya, V. Ravichandran, S. K. Kashaw and R. K. Agrawal, Bioorg. Med. Chem., 2012, 20, 3378-3395; (i) M. Stojanović, Z. Džambaski, B. Bondžić, J. Aleksić and M. BaranacStojanović, Curr. Org. Chem., 2014, 18, 1108-1148.

2 (a) B. A. Sobin, J. Am. Chem. Soc., 1952, 74, 2947-2948; (b) I. O. Edafiogho, C. N. Hinko, H. Chang, J. A. Moore, D. Mulzac, J. M. Nicholson and K. R. Scott, J. Med. Chem., 1992, 35, 2798-2805; (c) T. Kato, T. Ozaki, K. Tamura, Y. Suzuki, M. Akima and N. Ohi, J. Med. Chem., 1999, 42, 3134-3146; (d) N. Sokolenko, G. Abbenante, M. J. Scanlon, A. Jones, L. R. Gahan, G. R. Hanson and D. P. Fairlie, J. Am. Chem. Soc., 1999, 121, 2603-2604; (e) R. F. George, Eur. J. Med. Chem., 2012, 47, 377-386.

3 A. Rašović, P. J. Steel, E. Kleinpeter and R. Marković, Tetrahedron, 2007, 63, 1937-1945.

4 A. Rašović, A. Koch, E. Kleinpeter and R. Marković, Tetrahedron, 2013, 69, 10849-10857.

5 (a) R. Marković and M. Baranac, Synlett, 2000, 607-610;

(b) M. Baranac-Stojanović, J. Tatar, M. Stojanović and R. Marković, Tetrahedron, 2010, 66, 6873-6884.

6 R. Marković, M. Baranac and M. Stojanović, Synlett, 2004, 1034-1038.

7 (a) R. Marković, M. Baranac, P. J. Steel, E. Kleinpeter and M. Stojanović, Heterocycles, 2005, 65, 2635-2647; (b) M. Stojanović, R. Marković, E. Kleinpeter and M. BaranacStojanović, Org. Biomol. Chem., 2012, 10, 575-589.

8 M. Baranac-Stojanović, J. Tatar, E. Kleinpeter and R. Marković, Synthesis, 2008, 2117-2121.

9 R. Marković, A. Rašović, M. Baranac, M. Stojanović, P. J. Steel and S. Jovetić, J. Serb. Chem. Soc., 2004, 69, 909-918.

10 For selected literature on push-pull alkenes, see: (a) J. Sandström, Top. Stereochem., 1983, 14, 83-181; (b) G. Fischer, W.-D. Rudorf and E. Kleinpeter, Magn. Reson. Chem., 1991, 29, 212-222; (c) E. Kleinpeter, S. Klod and W.-D. Rudorf, J. Org. Chem., 2004, 69, 4317-4329; (d) E. Kleinpeter, A. Schulenburg, I. Zug and H. Hartmann, J. Org. Chem., 2005, 70, 6592-6602, and references therein; (e) E. Kleinpeter, J. Serb. Chem. Soc., 2006, 71, 1-17; $(f)$ P. Rattananakin, C. U. Pittman, Jr., W. E. Collier and S. Saebø, Struct. Chem., 2007, 18, 399-407; (g) H. Meier, B. Mühling, J. Gerold, D. Jacob and A. Oehlhof, Eur. J. Org. Chem., 2007, 625-631; (h) G. Ye, S. Chatterjee, M. Li, A. Zhou, Y. Song, B. L. Barker, C. Chen, D. J. Beard, W. P. Henry and
C. U. Pittman, Tetrahedron, 2010, 66, 2919-2927; (i) M. Baranac-Stojanović, U. Klaumünzer, R. Marković and E. Kleinpeter, Tetrahedron, 2010, 66, 8958-8967.

11 R. Marković, M. Baranac, N. Juranić, S. Macura, I. Cekić and D. Minić, J. Mol. Struct., 2006, 800, 85-92.

12 R. Marković and M. Baranac, Heterocycles, 1998, 48, 893-903.

13 R. Marković, A. Shirazi, Z. Džambaski, M. Baranac and D. Minić, J. Phys. Org. Chem., 2004, 17, 118-123.

14 R. Marković, M. Baranac, Z. Džambaski, M. Stojanović and P. J. Steel, Tetrahedron, 2003, 59, 7803-7810.

15 Y. Zhao and D. G. Truhlar, Theor. Chem. Acc., 2008, 120, 215-241.

16 J. B. Foresman and A. Frisch, Exploring Chemistry with Electronic Structure Methods, Gaussian, Inc., 1996.

17 M. J. Frisch, G. W. Trucks, H. B. Schlegel, G. E. Scuseria, M. A. Robb, J. R. Cheeseman, G. Scalmani, V. Barone, B. Mennucci, G. A. Petersson, H. Nakatsuji, M. Caricato, X. Li, H. P. Hratchian, A. F. Izmaylov, J. Bloino, G. Zheng, J. L. Sonnenberg, M. Hada, M. Ehara, K. Toyota, R. Fukuda, J. Hasegawa, M. Ishida, T. Nakajima, Y. Honda, O. Kitao, H. Nakai, T. Vreven, J. A. Montgomery, Jr., J. E. Peralta, F. Ogliaro, M. Bearpark, J. J. Heyd, E. Brothers, K. N. Kudin, V. N. Staroverov, T. Keith, R. Kobayashi, J. Normand, K. Raghavachari, A. Rendell, J. C. Burant, S. S. Iyengar, J. Tomasi, M. Cossi, N. Rega, J. M. Millam, M. Klene, J. E. Knox, J. B. Cross, V. Bakken, C. Adamo, J. Jaramillo, R. Gomperts, R. E. Stratmann, O. Yazyev, A. J. Austin, R. Cammi, C. Pomelli, J. W. Ochterski, R. L. Martin, K. Morokuma, V. G. Zakrzewski, G. A. Voth, P. Salvador, J. J. Dannenberg, S. Dapprich, A. D. Daniels, O. Farkas, J. B. Foresman, J. V. Ortiz, J. Cioslowski and D. J. Fox, Gaussian 09 (Revision D.01), Gaussian, Inc., Wallingford, CT, 2013.

18 C. Peng and H. B. Schlegel, Isr. J. Chem., 1993, 33, 449-454. 19 C. Peng, P. Y. Ayala, H. B. Schlegel and M. J. Frisch, J. Comput. Chem., 1996, 17, 49-56.

20 A. Klamt and G. Schüürmann, J. Chem. Soc., Perkin Trans. 2, 1993, 799-805.

21 R. A. Kendall, T. H. Dunning Jr. and R. J. Harrison, J. Chem. Phys., 1992, 96, 6796-6806.

22 R. Marković, M. Pergal, M. Baranac, D. Stanisavljev and M. Stojanović, ARKIVOC, 2006, 83-90.

23 R. Marković, M. Baranac and Z. Džambaski, Heterocycles, 2004, 63, 851-860.

24 A. Forni and R. Destro, Chem. - Eur. J., 2003, 9, 5528-5537. 25 Only for $\mathrm{CONH}\left(\mathrm{CH}_{2}\right)_{2} \mathrm{Ph}$ and CONHPh substituents, the order is reversed to that previously published. 